\section{A Brushing Apparatus for Height Control of Bedding Plants}

\author{
M ichael A. Schnelle, \\ B. D ean M cC raw, and \\ Timothy J. Schmoll
}

Additional index words. growth regulation, Lycopersicon esculentum M ill., tomato, daminozide

\begin{abstract}
Summary. H eight control for vegetable transplants has become challenging with the loss of the industry standard growth regulator, daminozide (Alar). O ne alternative to growth regulators- brushing - was conducted on two cultivars of Lycopersicon esculentum M ill. Five weeks of brushing twice daily resulted in height suppression for both tomato cultivars. B rushing treatments were performed successfully by use of a grower-designed apparatus constructed from readily available materials.
\end{abstract}

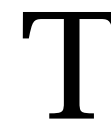

he ban of daminozide (Alar, U niroyal Chemical Co., M iddlebury, Conn.) on any edible crop has forced vegetable transplant growers to seek other methods for height control. N umerous methods of height control have been tested for bedding plants, including container size (Weston and Zandstra, 1986), copper sulfatefilters(Benson and Kelly, 1990), seismic (shaking) responses ( $L$ atimer et al., 1986), temperature (DIF) (H eins and Erwin, 1990), nutrition (M elton and D ufault, 1991), and drought stress (M cKee, 1981). Thigmomorphogenic responses of plants (response to brushing) also have been studied as an alternative to chemical growth regulation, especially for vegetable transplants.

Workers have reported reduction

D epartment of $\mathrm{H}$ orticulture and Landscape A rchitecture, Oklahoma StateU niversity, Stillwater, OK 74078

We thank R ae and Lyle Blakely, Creekside Plants, O ologah, Okla., for their ingenuity and contribution of time, labor, and greenhousespace. The cost of publishing this paper was defrayed in part by the payment of page charges. U nder postal regulations, this paper ther efore must be her eby marked advertisement solely to indicate thisfact. in stem elongation ranging from $15 \%$ to $50 \%$ depending on the vegetable transplant species/ cultivar treated (Baden and L atimer, 1992). Potential benefits from brushing include a sturdier, darker-green plant ( $L$ atimer and $M$ itchell, 1988), rendering the plant more aesthetically pleasing for retail and more likely to tolerate shipping and field transplanting ( $L$ atimer, 1990). Latimer (1991) offered a review of mechanical conditioning for control of growth and quality of vegetable transplants.

The objectives of this study were to determinetheeffectiveness of brushing for height control of tomato transplants, and to observe a grower'singenuity to construct a practical, costeffective apparatus made from readily available materials and manageable by one employee.

\section{$M$ aterials and methods}

Lycopersicon esculentum M ill. ' $\mathrm{Ce}$ lebrity' and 'Jet Star' were planted from seed and, upon germination, were transplanted to $3.7 \times 3.7-\mathrm{cm}$ cell packs and grown in a 1 sphagnum peat : 1 perlite : 1 vermiculite mix (by volume). Brushing began upon transplanting and the plants were handwatered uniformly as needed, receiving constant fertilization at $\approx 250 \mathrm{ppm}$ (mg.liter $\left.{ }^{-1}\right) \mathrm{N}$ and grown under temperature of $\approx 18 / 16.5 \mathrm{C}$ (day/ night).

No commercially available brushing apparatus exists. Therefore, the participating grower designed and built her own brushing apparatus (Fig. 1). G rower concerns in designing the apparatus were costs and time and ease of application of the brushing treatments, as well as flexibility of employment of the device in various areas of the greenhouse. To achieve maximum flexibility of employment, the device was built independently of the bench. The track guide, as well as the variable width adjustments (Fig. 1), precluded the need for hard-surface walkways and allowed the device to be used on any bench in the greenhouse. The prototype in Fig. 1 (dimensions of about $6 \times$ 5 feet) was constructed at a cost of about $\$ 200$. The materials used were heavy enough to provide the necessary stability, yet light enough to allow one person to apply the brushing treatment. Brushing was performed twice daily by pulling or pushing thefour-bar apparatus across the upper quarter of the seedlings 10 times, thus physically stroking each plant 40 times twice per day. The multibarred apparatus design reduced the number of trips back and forth per brushing treatment. Thefourbarred design provided adequateheight control as much as earlier models described in the literature (Baden and Latimer, 1992), but potentially with only $25 \%$ of thetimeinvestment needed for a single-bar apparatus. With the lightweight design and metal track system, thegrower wassuccessful in applying the treatments herself. The same individual performed thebrushing each day for treatment consistency, devoting $<5 \mathrm{~min} /$ day to treatments for a $5 \times$ 8 -foot bench. Brushing treatment continued daily, with thefour barsadjusted higher aswarranted by seedling growth. The grower used visual observations to determine when to raise the bar to restrict contact to the upper $25 \%$ of the plants' youngest growth. Plants on an adjacent bench were grown in an identical manner, except that they were not brushed throughout thestudy. Six plants were selected at random from each treatment and measured after 5 weeks of brushing (Table 1 ).

\section{Results}

Thebrushing treatment controlled transplant height (Table 1). The two cultivars ( 'Celebrity' and 'J et Star') were depressed significantly in height$26 \%$ and $35 \%$ respectively, in comparison to control plants. This reduction, although adequate for the grower's needs, was less than that achieved with other tomato cultivarsin an earlier study (Baden and Latimer, 1992).

The grower achieved the other goal of successfully constructing a relatively inexpensive brushing apparatus from commonly available materials. Also, the grower estimated that the shelf life of the brushed plants was extended $\approx 2$ weeks, thus potentially reducing lost sales. Customersfavored the dark-green, compact plants, and thus were willing to purchase older plants. The grower intends to refine the brushing technique and pursue it on a larger scale next season.

\section{Problems encountered}

Should different crops of varying germination periods and ultimate mature heights be grown on one bench, it would beimpossibleto adjust theheight of thebrushing apparatusto satisfyall of the species' growth needs. Also, various species grown on one bench would 
Fig. 1. I sometric view of brushing apparatus.

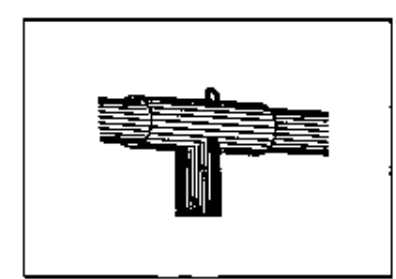

Detail A

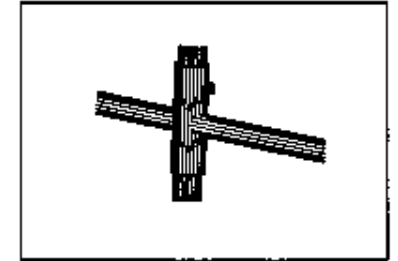

Detail B

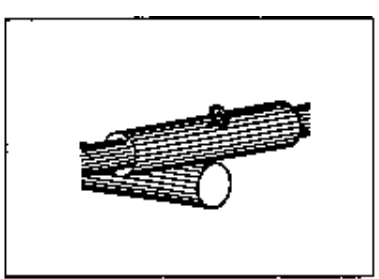

Detail C

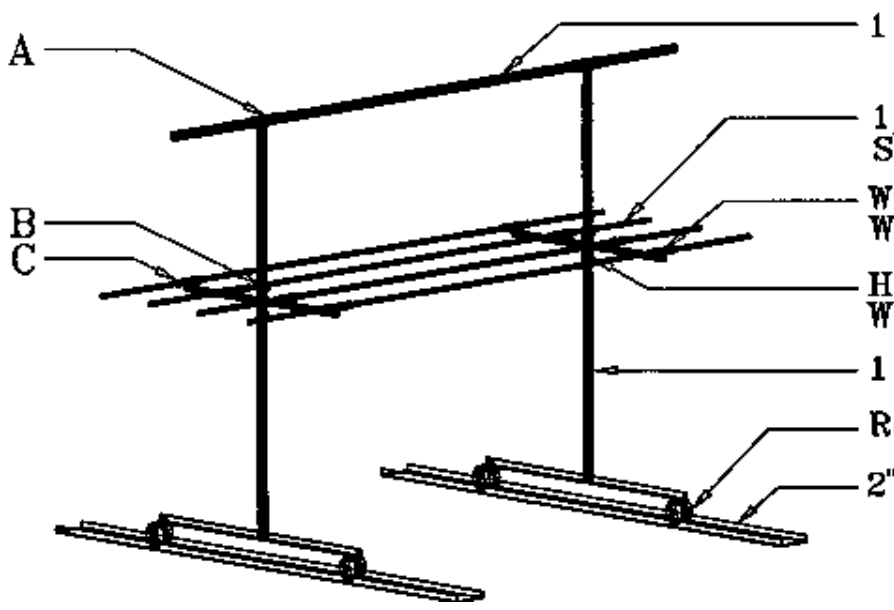

1 1/2" Metal Conduit Pipe

$1 / \mathcal{Z}^{\prime \prime}$ Metal Conduit Encased in Sehedule 40 PVC Pipe

Width Adjustment Fitting

With Thumb Screw

Height Adjustment Fitting

ith Thumb Screw

1/2" Metal Conduit Pipe

Roller

Channel Iron Guide Track

likely respond to brushing in varying degrees of height control (Latimer, 1991). Therefore, cropsmust besegregated by natural growth characteristics (particularly height) in order to mix crops on one bench. I deally, monocultures should be grown on each bench. Specific brushing treatmentsthen could be applied and then terminated when height control was achieved, as the effects of brushing are temporary. $\mathrm{Re}$ gardless of the crops being grown, brushing should be performed only on a dry canopy to prevent mechanical damage to the seedlings (Baden and Latimer, 1992) and to preclude the possibility of diseasespread (Vavrina, 1993).

In addition, the grower's bench was constructed of welded mesh wire, which tended to sag, except near the bench's periphery. The sagging bench prevented crops from being placed at the exact same height prior to brushing treatments. Consequently, all bench surfaces must be level and constructed of high-quality, sturdy materials to

Table 1. R esponse of $L$. esculentum trans plants to brushing initiated at the first-true leaf stage.

\begin{tabular}{lccc}
\hline & \multicolumn{2}{c}{ H eight $(\mathbf{c m})^{\mathbf{z}}$} & \\
\cline { 2 - 3 } Cultivar & Control & Brushed & Significance \\
\hline Celebrity & 23.5 & 17.4 & $*$ \\
Jet Star & 24.7 & 16.1 & $*$
\end{tabular}

${ }^{2} M$ eans for each cultivar are based on six plants selected at random per treatment.

* Significant at $\mathrm{P}=0.05$ by $\mathrm{F}$-test. achieve uniformity in height-control response. The other alternative is periodic rotation of the plants' position on the bench. H owever, this would not be feasiblein most commercial operations. L ast, the floor itself was somewhat uneven, creating the same problem encountered with the benches. In this case, floorsmust be even or the tracks of the brushing apparatus must be rendered level to compensatefor thisevent.

\section{F uture work}

O klahoma cooperators are interested in automating the apparatus and comparing the brushing technique described above against fans producing intermittent concentrated air blasts. Air blasts should induce a thigmomorphogenic response as well. L ast, growers are interested in comparing crop yields of brushed vegetable transplants against plants grown conventionally.

\section{Literature $\mathbf{C}$ ited}

Baden, S.A. and J.G. Latimer. 1992. An effective system for brushing transplants for height control. H ortT echnology 2(3):412-414.

Benson, J. and J. Kelly. 1990. Effect of copper sulfate filters on growth of bedding plants. H ortScience 25:1144. (Abstr.).

Beyl, C.A . and C.A. Mitchell. 1977. Automated mechanical stress application for height control of greenhouse chrysanthemum. $\mathrm{H}$ ortScience 12(6):575-577.
H eins, R and J Erwin. 1990. U nderstanding and applying D IF. G reenhouse G rower 8(2):73-76.

Latimer, J.G., T. Pappas, and C.A . M itchell. 1986. Growth responses of eggplant and soybean seedlings to mechanical stress in greenhouse and outdoor environments. J. Amer. Soc. H ort. Sci. 111(5):694-698.

Latimer, J.G. and C.A. Mitchell. 1988. Effects of mechanical stress or abscisic acid on growth, water status, and leaf abscisic acid content of eggplant seedlings. Scientia H ort. 36:37-46.

Latimer, J.G. 1990. D rought or mechanical stress affects broccoli transplant growth and establishment but not yield. HortScience 25(10):1233-1235.

Latimer, J.G. 1991. M echanical conditioning for control of growth and quality of vegetabletransplants. $\mathrm{H}$ ortScience26(12): 1456-1461.

M cK œ, J.M .T. 1981. Physiological aspects of transplanting vegetablesand other crops. I. Factorswhich influencere-establishment. H ort. Abstr. 51:265-272.

M elton, R.R . and R.J. D ufault. 1991. N itrogen, phosphorus, and potassium fertility regimesaffect tomato transplant growth. H ortScience 26(2):141-142.

Vavrina, C. 1993. Florida Veg. T ransplant Growers N ews 4(2):2.

Weston, L.A. and B.H. Zandstra. 1986. $E$ ffect of root container sizeand location of production on growth and yield of tomato transplants. J. Amer. Soc. H ort. Sci. 111(4):498-501. 